\title{
Universiteit
}

Leiden

The Netherlands

\section{Constraining external governance: interdependence with Russia and the CIS as limits to the EU's rule transfer in the Ukraine.}

Dimitrova, Antoaneta; Dragneva, R.O.

\section{Citation}

Dimitrova, A., \& Dragneva, R. O. (2009). Constraining external governance: interdependence with Russia and the CIS as limits to the EU's rule transfer in the Ukraine. Journal Of European Public Policy, 16(6), 853. Retrieved from https://hdl.handle.net/1887/14291

Version: $\quad$ Not Applicable (or Unknown)

License: $\quad$ Leiden University Non-exclusive license

Downloaded from: https://hdl.handle.net/1887/14291

Note: To cite this publication please use the final published version (if applicable). 


\title{
Constraining external governance: Interdependence with Russia and the CIS as limits to EU's rule transfer in the Ukraine
}

Antoaneta Dimitrova and Rilka Dragneva

\begin{abstract}
The question of how effective EU's external governance is cannot be answered without looking at the broader geographical and historical framework in which the Union extends its influence. We argue that interdependence between Ukraine and Russia in several key aspects shapes the context within which the EU and Russia compete to export their policies. Based on an analysis comparing the institutional rules underpinning EU's external governance and the CIS rules as well as several sectoral analyses, we show that the effectiveness of external governance varies with the patterns of interdependence. We identify sectoral differences in the extent of Ukraine's interdependence with Russia: it is low and receding in trade; medium in foreign policy and high in energy.
\end{abstract}

Key words: external governance, EU, Russia, Ukraine, energy, trade

\section{Introduction}

External governance, as elaborated earlier in this volume, is a way for the European Union (EU) to extend a common system of rules beyond its legal and geographical borders (Lavenex, 2004, Lavenex and Schimmelfennig in this volume). In this paper we argue that the question of 
how effective EU's external governance is cannot be answered without looking at the broader geographical and historical framework in which the EU extends its influence. Ukraine, a state with ambitions to join the EU, a close neighbor of Russia, is a suitable test case to address the question how EU's external governance is affected by other powers.

We conceptualize external governance as a way for the EU and neighbouring countries to cope with interdependence. The EU's external governance, especially when it involves institutionalized frameworks for political dialogue, networks or non-state actors, contrasts to Russia's traditional politics of power, aiming to re-establish Russia's influence over neighbouring states as a regional hegemon. Russia's policies are also sometimes embedded in the regional framework of the Commonwealth of Independent States (CIS), created as a tool for coping with interdependence after the USSR disintegration. Russia's power, inside or outside the CIS, has the potential of interfering with EU's external governance and its ability to lead to policy transfer in several ways. First, by using existing institutional commitments in the CIS framework, its framework of bilateral agreements or other mechanisms of formal coordination. Second, by exercising power policies in areas, where interdependence (structural, geopolitical, economic) is high. The existence of such constraints has important implications, ranging from delineating a clear limit to what the EU can achieve in its neighbourhood policies to requiring internal EU policy adjustments to take into account Russia's presence, as for example with energy policy. 
Even though external governance has been developed as a theoretical perspective that moves away from traditional geopolitical analyses, the different character of EU external governance does not eliminate the need to consider power. Given the fact that Russia, as a centre of power, poses very considerable constraints for EU external governance, we put interdependence ${ }^{1}$, the key variable determining Russia's power and ability to limit EU's policy extension, at the centre of our analysis. Rather than arguing, as the institutional model formulated by Lavenex and Schimmelfennig (2009) does, that the degree of existing institutionalization affects the success of external governance, we see interdependence as the driving force for institutionalization. For example, the EU started formulating an energy strategy and institutionalizing a policy internally because it needs to deal with energy dependence on Russia and transit dependence on Ukraine. In such cases, EU institutional rules appear to be the effect, rather than the cause of developments in the foreign policy arena. Therefore, we argue, in line with the power model formulated by Lavenex and Schimmelfennig (2009) that interdependence with Russia is a key variable defining the effectiveness of EU's external governance.

Based on an analysis of the institutional rules underpinning EU's external governance as well as several sectoral analyses, we argue that the effectiveness of external governance in terms of rule selection, adoption and implementation (Lavenex and Schimmelfennig, in this volume) varies with the patterns of interdependence. We suggest that different kinds of 
interdependence between Ukraine and Russia - legacy-driven, structural/ institutional, geo-political or finally, economic interdependence - define the context within which the EU and Russia compete to export their policies and rules.

Before we analyse how EU external governance and Russia's power interact in different policy areas in Ukraine, we first outline the existing system of institutional and legal rules that make the formal foundation of EU or CIS governance. Next, we examine rule adoption driven by the EU's external governance in three different policy areas, namely 'deep trade', energy, and foreign and security policy. The levels of interdependence between Russia and Ukraine in these policy areas vary from low to high. Based on this variation, we show that different patterns of interdependence with third states can present different level of constraints to EU rule transfer.

\section{Comparing institutional underpinnings of governance ${ }^{2}$}

\section{EU - Ukraine institutional and legal relations}

The interactions between the EU and Ukraine have been so far defined by EU's reluctance to acknowledge Ukraine as a full-fledged candidate for membership. The possibility of enlargement remains, however, a crucial feature that characterizes EU-Ukraine relations. The reason why this is important is that, just as it was in the early phases of the EU's enlargement

to the East, the Union's ability to govern (externally) is derived from the 
prospect of membership (Friis, 1998:6). This prospect introduces in EUUkraine relations the asymmetry that we know from accession negotiations. Since the EU has not made the Ukraine an official candidate, many of the tools and instruments that express the power asymmetry such as Accession partnerships cannot be used. The existing tools and institutional arrangements that underpin external governance, for example the Partnership and Cooperation Agreement (PCA), bear the imprint of the power asymmetry and indicate the predominance of the hierarchal mode of governance defined in this volume. Through these institutions, the EU exercises its power in a technocratic, low key mode, yet the asymmetry remains and can be seen in the elements of conditionality existing in all institutional agreements and instruments.

The PCA between Ukraine and the EU was signed in June 1994 and entered into force in March 1998. From an institutional point of view, it creates several bilateral organs which, as with other EU agreements with third countries (and especially the EU's Association Agreements with Central and Eastern Europe), have the potential to take a life of their own in shaping the common regime. The institutions create conditions for EUUkraine political and expert dialogue. The provisions for structured meetings at different levels ${ }^{3}$, from leaders' summits to senior civil servants, parliamentarians and experts, provide for a possibility for network governance to develop. 
The PCA provides further for considerable projection of EU rules: 'The rules of the PCA introduce extensive, legally binding commitments with considerable implications for the domestic legislation of Ukraine' (European Commission). How binding these commitments are, however, varies between the specific provisions. The trade provisions of Title III are fairly precise and impose clear, enforceable obligations. Other provisions, e.g. in the area of labor cooperation, amount to no more than 'best endeavour' clauses and compliance with these depends on the overall disciplinary framework of the PCA.

It is important to note that the approximation of Ukrainian legislation to the EU is among the main priorities and determinant features of the PCA regime. Article 51 contains a list of areas which are to be included in the approximation process. As formulated, the article provides for a voluntary endeavor on the part of Ukraine to make its legislation compatible with the EU. Thus, it stops short of a 'hard' obligation for adoption of the acquis, which would materialize should Ukraine become an official candidate for membership.

The PCA does not contain any references to membership and neither does it have provisions suggesting pre-accession conditionality. It does, nevertheless, contain conditionality. In particular, Article 2 of the PCA defines respect for the principles of market economy as an essential element of the EU-Ukraine partnership. The consensus is that when Article 2 is read in combination with the suspension clause of Article 102 ('The Bulgaria 
clause') and the 'material breach' requirement of Article 60 (3) (b) of the Vienna Convention on Law of Treaties, amounts to a complex suspension procedure in case of a failure to comply with democratic principles and market mechanisms. ${ }^{4}$

Another important aspect of the PCA regime relates to its dispute resolution provisions as a disciplinary mechanism. The PCA envisages a special procedure, whereby parties submit disputes to the Cooperation Council or, in case of its failure to resolve them, to a number of conciliators (Article 96, PCA). Similarly, under Article 102, parties are allowed to take 'appropriate measures' in case of a failure of the other party to fulfill an obligation, which normally require notification to the Council. The decisions of the Council or the mediator, however, have only the power of recommendations.

The development of the European Neighbourhood Policy (ENP) of the EU added a new dimension to the partnership relations with Ukraine. It is, however, primarily a set of institutional, legal and policy arrangements that respond to the EU citizens' desire for 'prosperity, security and stability' (Ferrero-Waldner, 2006). The ENP has also been aptly characterized as an adaptation of enlargement policies to the foreign policy domain (Kelley, 2006: 29). It relies on the legal and institutional structure of the PCA. The central instrument of this policy towards the Ukraine - the Action Plan (AP) of 2005, is a 'soft law' document, adopted as a Recommendation of the PCA Cooperation Council (Cremona and Hillion, 2006). 
While denying membership, the AP seeks to strengthen the positive aspects of conditionality by promising enhanced economic integration, or a 'stake in the internal market', 5 and a set of rewards. It envisages clear benchmarks in the political and economic sphere which would trigger deepening of the relationship. Alongside these concrete steps, the AP arguably also strengthens the 'values' conditionality of the PCA, as progress is dependent on the adoption of the 'shared values' at the core of the ENP.

The AP contains the promise of a new Neighborhood Agreement to supplement the existing framework, which would provide for 'new entitlements and obligations' (Action Plan). There is currently a great deal of expectation and discussion regarding the nature, contents and legal basis of this agreement (Hillion, 2007, Shapovalova, 2008, Sushko et al, 2008). Even though it has still some way to go, some key elements are already clear. Deep trade provisions would be central. The core of the agreement would define areas of cooperation as the main dimensions of the external governance projected towards the Ukraine.

Clearly, domestic Ukrainian institutions and politics are also a key variable determining the success of conditionality and external governance as a whole. There are, however, other rules and agreements which play a role in Ukraine's case - these of the CIS.

\section{Ukraine - CIS/SES/Russia relations}


The CIS is a regional integration structure that seems, at first sight, to serve a similar function as the EU and other regional integration bodies, namely, to help its members deal with interdependence. Previous analyses, however, show that CIS does not provide 'hard law' constraints to its members' actions and does not require irreversible commitment from them. It can be identified as a 'soft' regime remaining short of inducing formal compliance in the countries which have signed up to it (Dragneva, 2004). Yet despite serious institutional weaknesses of the CIS and the ambivalence of Ukraine's position within it (Dragneva and Dimitrova, 2007), the CIS remains an important reference in Ukraine's international relations.

Ukraine is represented in most of the common institutions of the CIS. It has made a maximum use of the flexibility of the organization's institutions in order to minimize any loss of sovereignty. Yet, Ukraine continues to be a regular party to the structured political dialogue taking place at the various CIS meetings. Even in cases when Ukraine has eventually decided not to sign a certain CIS decision or agreement, it has frequently taken part in the process of its preparation.

In addition to structured political dialogue, a key function of the organs of the CIS is to serve as a medium for cooperation in areas of common interest through the conclusion of international agreements. Cooperation within the CIS is structured through a multiplicity of international agreements - multilateral and bilateral. Thus, the undertaking of any 
commitments and the extension of any common rules remains firmly within the sphere of international law.

In its range of areas for cooperation, the CIS can be described as a 'broad house'. Some areas can be characterized by greater intensity of cooperation and efforts to build a multilateral framework, such as trade (Dragneva and De Kort, 2007). Yet, the international regime in most of them can be characterized as particularly loose and soft. Even when Ukraine has chosen to sign certain agreements, it has frequently used various devices to mitigate the legal effects of the commitments made in them, such as reservations, general or vague provisions, delayed ratification (Dragneva, 2004). The CIS is also known for its 'spaghetti bowl' of agreements, leading to conflict of rules, uncertainty and lack of coherence (Freinkman et al., 2004).

Importantly, Ukraine's position in the CIS institutional framework is subject to weaker disciplines or sanctions. It has chosen not to participate in the CIS Economic Court set up in 1992. The 1994 Free Trade Agreement, signed by Ukraine, envisaged a dispute resolution sequence of measures including resort to the Economic Court. Yet, such a provision is more the exception rather than the rule and Ukraine has not been involved in a dispute brought before that Court.

Given the specific institutional features of the CIS regime, its effectiveness ultimately depends on Ukraine's will to be bound by it. Thus this regime does not amount to a legal constraint to EU's external 
governance. The level of Ukraine's involvement in the CIS arrangements, however, can be changed and is potentially subject to influence from Russia.

When discussing possible constraints for EU's external governance, it is important to refer also to one of the sub-regional organizations created within the post-Soviet space, that of the Single Economic Space (SES). This formation causes some concerns in view of the compatibility of the commitments undertaken by Ukraine and those undertaken towards the EU, which mostly stem from the institutional structure of the SES. Importantly, the founding Agreement of 2003 provides for a 'single regulating organ' with some supranational elements to which participating states would delegate competences on the basis of international agreements (SES Agreement, 2003: Articles 4 and 7). Further, this Agreement sets up a very minimal and general regime for the SES. Its provisions resemble more statements of intent rather than a basis for credible legal obligations. One of the main principles of the SES, like the CIS, is 'variable-level and variablespeed integration' (SES Agreement, 2003: Article 5) where countries determine for themselves to what extent and in what frameworks to participate.

Despite the fact that Ukraine has defined its interest in SES primarily in terms of free trade - it is clear that the SES is another forum for high-level dialogue. The initial expectation that Ukraine will be formally pulling out of it did not materialize; on the contrary, there have been indications of plans to play an active role in shaping it (Timoshenko, 2005, Terekhin, 2005). ${ }^{6}$ 
The overview of the EU's external governance as projected through the PCA and ENP versus the CIS/SES suggests that the EU is clearly more advanced in using institutions to structure governance and to project policies. This does not mean, however, that Russia's role can be neglected. Interdependence in specific areas creates a crucial opening for Russia to exercise power in a more traditional sense, even if it does not channel it through CIS institutions. In the following sections, we start by examining a sectoral area with receding interdependence, namely trade. We proceed to look at an area where arguably more interdependence exists (foreign policy) and finally analyze an area which is a textbook case of high interdependence between Russia and the Ukraine: energy. We seek to show that EU's ability to influence policies and transfer its own rules is constrained by Russia's power in cases where interdependence is high. In cases when interdependence is lower, the EU appears to be more successful in projecting its rules.

\section{Policy regimes: Trade}

Ukraine - EU

Given the EU's core competences in trade and economic integration, trade is a policy area where we have seen sustained EU efforts to extend its 
rules or promote compatible rules. Trade relations have been in the heart of EU and Ukraine relations as set up by Title III of the PCA and by specific sectoral agreements. ${ }^{7}$ These relations were given a boost and prioritized more specifically with the adoption of the Ukraine-EU Action Plan of 2004, and more recently with the accession of the Ukraine to the World Trade Organization (WTO) in 2008 and the negotiations for an enhanced neighbourhood agreement.

The contents of the EU-Ukraine regime has been discussed at greater length elsewhere (Dragneva and Dimitrova 2007, World Bank, 2004). An important feature of this regime is the progressive liberalization and evolution of the regime leading to larger volumes of trade between the two sides. For example, an important step was made with the recognition of the Ukrainian economy as a 'market economy' in December 2005, which lowered the severity of special protective measures still allowed under the PCA (Emerson et al, 2006: 51). The Ukraine's WTO accession in 2008 was critical in respect of abolition of quantitative restrictions or equivalent trade barriers and liberalization of trade in steel and textiles. It allowed the start of the negotiations on a 'deep and comprehensive' free trade agreement as part of the new Enhanced Neighbourhood Agreement.

Table 1: Trade balance (exports and imports) of the Ukraine in 1990 - 2007

\begin{tabular}{|l|l|l|l|l|l|l|}
\hline & 1990 & 1993 & 1996 & 1999 & 2003 & 2007 \\
\hline Exports & 100 & 100 & 100 & 100 & 100 & 100 \\
\hline
\end{tabular}




\begin{tabular}{|c|c|c|c|c|c|c|}
\hline $\mathrm{RF}$ & 54.6 & 34.8 & 38.7 & 20.4 & 18.7 & 21.9 \\
\hline Rest of CIS & 26.6 & 11.5 & 12.7 & 7.3 & 7.5 & $6.9^{*}$ \\
\hline$\overline{E U}$ & 5.6 & 6.4 & 11.1 & 20.5 & 19.8 & 30.6 \\
\hline Baltics & 1.7 & 1.1 & 1.8 & 1.5 & 3.8 & n.a. \\
\hline Imports & 100 & 100 & 100 & 100 & 100 & 100 \\
\hline $\mathrm{RF}$ & 58.0 & 45.1 & 50.1 & 48.0 & 37.6 & 25.3 \\
\hline Rest of CIS & 20.3 & 19.0 & 13.4 & 9.8 & 12.4 & $8.6^{*}$ \\
\hline EU & 5.3 & 8.2 & 15.4 & 23.1 & 25.2 & 44.9 \\
\hline Baltics & 2.3 & 2.1 & 1.6 & 1.6 & 1.1 & n.a. \\
\hline
\end{tabular}

Sources: WB Trade Policy Study, November 2004. Regarding 2007 data: EU Trade

statistics, Ukraine, 2008.

* the number refers to major CIS partners only.

Secondly, it is important to note the extent of rule transfer inherent in the evolution of the trade regime. The PCA contained an evolutionary clause for the establishment of a free trade area subject to the advancement of economic reform in Ukraine and the development of the PCA trade regime (PCA, Article 4). This clause did not introduce a hard obligation, yet it was indicative of the long-term intentions of the parties. A further impetus to the development of the trade regime was given with the adoption of the ENP policy and the 2004 Action Plan. The AP emphasized the full implementation of the provisions of the PCA and particularly the approximation of Ukrainian legislation, norms and standards to those of the EU' (AP, 2004). Further advancements in the trade regime were critically dependent on Ukraine's progress in its WTO accession. Thus, the adoption of the WTO acquis, applicable to the EU as well, was an essential aspect of 
the rule transfer process. This suggests, as argued by Barbé et al (2009) in this volume, that the EU's own norms are in some areas part of international sets of norms and taking a view focusing on the EU as the only norm maker is misleading.

Despite the issues still under negotiation, it is clear that 'deep trade' entails further harmonization of key aspects of the regulatory environment started with the PCA and detailed further in the AP. As Emerson et al. (2006) have shown, deep trade would affect not only a range of sectors (financial, energy, transport, etc), but also introduce parts of the EU acquis ranging from competition policy to corporate governance, labour and environmental standards. In fact, in its substantive scope a forthcoming deep trade agreement is better described as 'internal market minus' agreement (Gstöhl, 2008). Moreover, deep free trade, for the EU, is embedded in ideas of the Neighbourhood Economic Community or the most recent Eastern Partnership initiative, aiming for a common regulatory space in the neighbourhood region (European Commission, 2006: 5).

Thus, clearly, in trade the EU has a comprehensive rule transfer agenda, strengthened by the WTO context. Yet, the EU has also had to take into account the trade relations of the Ukraine and Russia/CIS and the extent to which the CIS has represented a competing provider of rules and policy export.

Ukraine - CIS/SES/Russia 
Within the Soviet Union, Ukraine was part of a single market and all trade was in effect domestic trade. The break-up of the Union saw the rapid disintegration of this economic system, which the new independent states sought to contain through the CIS. They also embarked on a new course of reintegration largely driven by and centered around Russia (Dragneva, 2004, Dragneva and De Kort, 2007). It is important to note the extent of this reintegration in the area of trade and the degree to which it can restrain EU external governance.

Ukraine operates a free trade regime with the CIS based on a complex set of bilateral and selective multilateral engagements (Dragneva and De Kort, 2007, Dragneva and Dimitrova, 2007). This regime does not cover all trade in the sense that it allows for exemptions to be negotiated in separate protocols. ${ }^{8}$ Its effectiveness is diminished by the possibility to apply unilateral special protection measures without adequate provisions in terms of dispute resolution on their adoption or interpretation. In effect, there has been a succession of "trade wars" between Russia and Ukraine in which relations have escalated through reciprocal measures (World Bank, 2004). The trade regime, despite its evolution through the years, can be described more as a 'simple' rather than a 'deep' free trade, characterized by a weak institutional basis (Dragneva and De Kort, 2007).

The CIS regime entails some level of harmonization particularly in the area of customs legislation and administrative practice. Another key area, 
largely reflecting inherited interdependencies, is that of technical standards. CIS Member States inherited the USSR system of standards (GOST) which was not recognized in the rest of the world. For example, one of the early multilateral CIS agreements provides for the recognition of the USSR standards as international standards for the CIS countries. The agreement also provided for policy coordination in standardization, metrology and certification through the special Intergovernmental Council (Dragneva and De Kort, 2007).

This regime, however, has failed to contribute to significant levels of trade reintegration. As Table 1 shows, trade decline has continued. There are many reasons for this, yet it has been argued that it is due to a large extent to the institutional and legal weaknesses of the regime (Freinkman et al, 2004). Administrative and other non-tariff barriers between CIS members continue to exist as a result of failed domestic reforms and low quality of governance and remain a crucial factor limiting trade.

Receding Interdependence in Trade and Few Constraints to EU Governance

In general, there are four reasons why Ukraine - CIS/Russia trade relations, as described above, do not represent a major competing centre to the EU. First, as explained above, the CIS is a weak, simple trade area. Secondly, Ukraine has maintained a position within the CIS which allows it a great deal of flexibility. An important feature of the free trade agreements 
is a standard clause whereby their provisions do not preclude participation in other organizations or agreements, which do not contradict their objectives and terms. ${ }^{9}$

Thirdly, the EU trade regime recognizes and encourages Ukraine's cooperation with former USSR states. It allows any free-trade or customs union arrangements (including such on free transit) made by Ukraine with its CIS partners (PCA: Articles 3, 11 and 12, Annex 1). Indeed, regional cooperation within the CIS has been one of the important premises of the PCA framework. Similarly, the ENP and the concept of Neighbourhood Economic Community promoted in 2006 focus on promoting regional cooperation.

Fourth, the process of adoption of the WTO acquis has an effect that minimizes rules clashes. Other than Ukraine, four other CIS countries are already members of the WTO (Kyrgyzstan, Armenia, Moldova and Georgia), and most of the others have advanced in their progress to adapting the WTO regulatory framework. As the review of free trade agreements concluded within the CIS shows, there are a growing number of references to WTO interpretations and norms (Dragneva and De Kort, 2007).

While current arrangements do not constrain the Ukraine in EU rule selection and adoption at present, a potential future deepening of the economic integration agenda within the CIS or SES would create incompatibilities (Emerson et al., 2006, Cremona, 2004)..${ }^{10}$ Such a deepening seems unlikely in the CIS, despite the fact that initially free trade was 
conceived as a first stage in the progressive achievement of an economic union. It remains a possibility, however, within the SES, which refers, in its founding documents, to the creation of an economic union. If Ukraine were to enter into a customs union with its SES partners (or another CIS constellation), it would be the union's institutions, not Ukraine that would renegotiate current (or pending) free trade arrangements with the EU, and vice versa, in the case of membership into the EU. Thus, participation in both an EU and a SES customs union would be impossible.

Importantly, the move to a 'deep trade plus' arrangements with the EU in the context of the New Enhance Agreement raises the level of commitment in terms of adopting various aspects of the EU acquis. Given the growing emphasis on regulatory harmonization, key aspects of Ukraine-CIS relations, such as the issue of technical standards mentioned above, assume even greater importance and constrain EU governance by affecting rule adoption and implementation. Given the benefits for the EU from continued free trade relations in the region, it has been argued that 'it would be desirable for Ukraine's CIS partners to also persuade their institutions to approximate to EU norms, rather than maintain idiosyncratic rules' (Emerson et al., 2006: 63).

Thus, in the area of trade, the EU external governance has been growing and effective in transferring the EU's (and WTO) rules. We see this in correlation with Ukraine's diminishing dependence on trade with Russia and the CIS. Significant trade reorientation has taken place and the share of 
CIS trade has decreased significantly (see Table 1). Yet, some economic and geographical interdependence between Ukraine, Russia and CIS remains. Russia is a key trade partner of Ukraine, particularly in the area of energy imports, as will be discussed below. There are important institutional legacies, such as in the area of standards, which will still affect EU rule adoption and implementation.

The next policy area, foreign policy, is one in which interdependence stems from important historical legacies and geographical proximity and constrains the EU's efforts to promote Ukraine's adoption of its foreign policy and addressing its security concerns.

\section{Policy regimes: Foreign and security policy}

Ukraine - EU

In contrast to the PCA, in the area of Common Foreign and Security Policy (CFSP) the EU is arguably trying to extend its own policies beyond its borders without extending the institutional framework. The alignment of Ukraine with EU's Common Positions and Joint Actions since 2000 and especially since 2005 suggests that Ukraine has taken on board EU policy to a considerable extent. ${ }^{11}$ In 2005, Ukraine had aligned itself with 549 out of 589 CFSP declarations, or 93\% (European Commission, 2006) and in 2007, 
Ukraine had aligned itself with 833 out of the total of 907 of relevant statements, or 92\% (Razumkov centre, National Security and Defense, 2007a:6). However, it is important to note the exceptions which include, significantly, EU joint actions and common positions regarding Belarus and the Southern Caucasus (see also Barbé at al 2009).

In crisis management, an important aspect of CFSP, Ukraine has signed an Agreement establishing its participation in EU crisis management operations (European Commission, 2006:5) and has been active in providing troops for peace keeping missions. Ukrainian participation in the EU Border Assistance Mission to Moldova and Ukraine (EUBAM) can be taken as an interesting example of policy convergence. Arguably, the EU projects its own demands for border security while at the same time the Union and Ukraine address a security need important for both Ukraine and Moldova.

Ukraine - CIS/Russia

Since the break-up of the Soviet Union, Ukraine has strived to lead an independent of Russia foreign policy and to pursue several vectors in its external relations. Yet, by virtue of both history and geography, it has repeatedly found itself in the position of having to align itself closer with Russia, particularly prior to 2004. Even after 2004, developments such as the recent conflict in Georgia reveal the limits to EU's 'soft' governance. 
In terms of the institutional framework of security relations, Russia has promoted a multitude of international treaties within the CIS. These treaties have covered a wide range of issues, such as terrorism, conventional weapons, and ethnic conflicts. The treaties provide for procedural cooperation, standardization and the formation of specialized governing bodies and organizational structures (Willerton and Beznosov, 2007). An example of how such treaties, seemingly dormant, can be reactivated and make an impact, was a CIS agreement on peacekeeping missions that, according to some, provided the justification for the Russian army actions in Georgia in August 2008 (Silina, 2008).

As Willerton and Beznosov note, the Ukraine has been selective and cautious in committing to the CIS treaties, while at the same time has, like other CIS countries, sought to distance itself from Russian dominance (2007). They show that Ukraine has signed 30 out of the 53 security agreements concluded in the period 1992-2004 (Willerton and Beznosov, 2007: 59). Wolczuk notes that it joined some only under extreme energy supplies related pressure by Russia (Wolczuk, 2007).

More important than these institutional arrangements has been interdependence in the form of inherited legacies such as the position of the Black Sea Fleet. The Russian Black Sea fleet, positioned in the Crimea, has been a constant source of worry for Ukrainians with its possible implications of foreign policy dominance. At the same time, Russia relies on Ukrainian facilities and infrastructure for the fleet. In 1997 the two countries reached an 
agreement, providing that from 2008 Russia would pay Ukraine market rent for facilities rented by the Russian Black Sea Fleet. Such payment would, among others, strengthen Ukrainian control over the stationing of the fleet. The practical implementation of this issue, however, was tied up in the Ukrainian 2008 budget law with the Ukrainian debt to Russia of 1.3 billion USD for gas (Silina, 2008). This example illustrates the complex interdependences not only within one policy sector, but also between sectors.

Interdependence with Russia remains an important factor in policy choice

On the whole, we can conclude that EU governance has been effective in policy transfer. Yet, in important areas driven by historical legacies and geopolitical interdependence, policy alignment and policy implementation have been significantly constrained. The non-alignment of the Ukraine with the EU's common position on Belarus, mentioned above, shows the country's response to regional interdependence despite its general decision to follow the EU's lead. Ukraine has declared that it shares the EU's views on the political regime in Belarus, but has consistently tried to mediate in a dialogue with Belarus, including high level meetings (Melyantsou and Kazakevich, 2008:70).

Importantly, the EU's ability to export its governance in foreign relations is also constrained by the resurging idea of Russia as a regional 
power and corresponding Russian policies, including violence. Analysts have pointed out that after 2003 and especially after Ukraine's 'Orange revolution', Russia has abandoned the idea of CIS as a liberal trade community and has embraced the idea of its regional power status instead (Krastev, 2005). During Putin's second presidency, there has been a consistent effort in reasserting Russia's traditional sphere of influence (Jonson, 2004, Vinokurov, 2007, Godzimirski, 2007). The Russian view of sovereignty is a much 'harder' concept than the EU's notion of fluid borders and multiple regimes. Following from this hard concept of sovereignty is the Russian idea that Ukraine is and should firmly stay in its sphere of influence.

The new Russian assertiveness in foreign policy has counteracted Ukrainian (and Georgian) aspirations to join NATO with effective lobbying, but also with politics backed by force: the actions of the Russian army in Georgia in August 2008. After the start of the conflict, Russia accused Ukraine of supplying arms to Georgia, leaving Ukrainians to wonder if the country was being provoked into conflict. Anatoliy Gritsenko, chairman of the Ukrainian Parliament's Security and Defense Committee, described Russian Foreign Ministry's statement that 'Ukraine has armed Georgia inciting it to intervention and ethic purges' as 'provocative, irresponsible and untrue' (Silina, 2008). Further, Ukrainian Deputy Foreign minister Yeliseyev stated that the presence of a large Russian minority in the Crimea, 
made Russian actions in Georgia a direct threat to Ukrainian security and the Ukraine a de facto third party in the conflict (Rettman, 2008).

The crisis which split the Ukrainian governing coalition in September 2008 started ostensibly as a result of the different responses of President Yushchenko and Prime Minister Timoshenko to the Russia-Georgia conflict. The former accused the latter of high treason for allegedly siding with Russia over the Georgian conflict. While this paper does not focus on domestic Ukrainian responses, this conflict indicates the extreme vulnerability of Ukraine to external influences due to domestic political and regional divisions.

Thus, we find evidence that interdependence with Russia in foreign policy has constrained EU external governance - partly in policy adoption and significantly in actual policy implementation. Yet the area where constraints stemming from interdependence are most visible is not foreign policy but energy.

\section{Policy regimes: Energy}

\section{Ukraine-EU}

Energy has been one of the priority areas of ENP since the beginning. It aims to enable integration with the European energy market, but also to 'help the countries concerned come in line with European standards and norms' 
(Ferrero-Waldner, 2006). Ukraine's integration into EU's energy market as a part of a deep trade arrangement requires the adoption of a set of regulatory standards.

The Ukraine is highly important for the EU as a transit country for gas coming from Russia. As an indication of this importance and of overall interdependence, $76 \%$ of the Russian gas comes to the EU via Ukraine, $20.3 \%$ is delivered via Belarus and $3.7 \%$ is delivered directly from Russia to Finland (Razumkov Centre, 2008).

The EU has a Memorandum of Understanding with Ukraine on Energy cooperation (2005). Ukraine's key role is mentioned in the Commission's Green paper on Energy (2006). The country gained observer status in the Energy Community Treaty in 2006 and applied for full membership in 2007. In 2007, the Commission allocated $€ 87$ million for the reform of the Ukrainian energy sector. The Commission and the Ukraine have agreed upon a selection priority projects in the electricity, gas and oil sectors (European Commission, 2008). Such actions encourage policy transfer through the network mode of external governance by funding projects involving a multitude of domestic actors. The gas crises in 2006 and 2009 when Ukrainian-Russian conflict disrupted severely gas supplies for EU members, have shown, however, that energy is still a matter of high politics.

Ukraine- Russia 
Energy has always been a key area within the CIS. The development of institutional structures has been promoted by Russia in selected areas (the CIS Electric Power Council from 1992), but Ukraine has participated selectively in such arrangements. It joined the Council in 1992, but refused to sign the Agreement on the Formation of a Common Power Market in 2007 (Vinokurov, 2008).

More importantly, and particularly in the critical area of oil and gas, Russia has maintained bilateral relations, which have taken place at the highest levels of negotiation and in an atmosphere of secrecy (De Souza, 2008). Further, intra-CIS trade has been plagued by non-transparent barter arrangements, discriminatory access to pipelines and corruption (Dodsworth et al. 2002, Stern, 2005). Energy interdependence has been explicitly used by Russia in the CIS context for political purposes (Godzimirski, 2007, Razumkov centre, 2007b). Russia's bilateral deals and contracts for gas deliveries with EU member states and Ukraine represent the best example of interdependence as a source of power which interferes with effective governance by the EU.

Gas and oil trade have become a traditional power arena, where states seek to capitalize on structural advantages. Russia has repeatedly used price and indirect taxation as a policy lever. It has exploited its monopoly over resources by limiting the supply of energy. This monopoly position is evident in relation to gas resources given that Russia supplies about $35 \%$ of Ukraine's consumption and controls the transit of other 
Ukrainian supplies (primarily from Turkmenistan) which amount to about $40 \%$ (De Souza, 2008). Given the Russian ownership of gas pipelines and the complexities of Turkmen foreign policy, this is an extreme dependence on one source which is very difficult to diversify.

In the area of oil, about $75 \%$ of consumption of Ukrainian refineries comes from Russia. Another important part is delivered from Central Asia (primarily Kazakhstan), again through Russian routes (De Souza, 2008, Emerson et al., 2006). Ukraine has tried to increase its bargaining power by using its geographical position as a transit country, raising transit fees and imposing other transit conditions on Russia. Yet, it remains unable to break its dependence on Russia. ${ }^{12}$

Interdependence patterns can be found also in business networks of actors in the energy field. Ukraine's energy related companies are often partly owned by Russian businesses and in need of restructuring. An example is Neftogaz, the Ukrainian gas company and the intermediary RosUkrEnergo. The latter has been sometimes described as a non-transparent network linked to those in power in both countries. There are several more non-transparent financial and industrial groups operating in the oil refining and coal mining sector, owned by Russian capital (Emerson et al. 2006). ${ }^{13}$

Another example of structural interdependence is demonstrated by the electricity sector. Ukraine's grid (except for a small segment), remains connected to the CIS grid, which has different technical characteristics from the European grid (Emerson et al. 2006). 
On the whole, existing interdependence within the CIS and with Russia - structural (technical), geographical and economic - constrains considerably EU policy transfer in the field.

Interdependence prompts institutionalization of new EU policies

In early 2006 and again in January 2009, conflicts between Russia and the Ukraine over the price of gas led to disruptions of the supply to Ukraine and EU member states. Mediation efforts by the Czech EU Presidency in the January 2009 had little success despite an agreement signed between Gasprom and Ukraine. This most recent gas crisis has made it clear to the EU that an energy policy of its own is the only way to tackle its own and Ukraine's dependence on Russian gas.

A truly common EU energy policy, engaging all the member states would make the EU position much stronger, but is resisted by Russia. Commenting on the proposed clauses in the Commission's third energy liberalization package that would make bilateral energy deals an EU competence, a source in Russia's Economic and Trade Ministry stated that 'damage from such politicizing of investment issues will be reciprocal, but will hit the European Union more severely' (Euractiv, 2008).

The Commission's energy liberalization plan from September 2008 contains a reciprocity clause ('Gasprom clause') that aims at inducing third countries to play by the EU's rules. In November 2008, the Commission 
proposed a new, wide-ranging energy package which aims to ensure energy security in Europe, including an EU Energy Security and Solidarity Action Plan (Commission, 2008c). The plan includes the objective of closer coordination between the member states in external energy relations, measures to make more efficient use of existing resources, build infrastructure to connect member states to each other's electricity grids and energy efficiency measures. These developments support our view that interdependence and consequent openings for Russia to exercise its power are the causal factors that may lead to institutionalization of energy policy in the EU. Existing institutional arrangements cannot provide for a successful projection of EU policies.

\section{In conclusion: constraints to the EU's external governance}

The comparison of the three policy areas above reveals a pattern of constraints to the EU's external governance that increase when there is high interdependence with Russia/the CIS. We summarize our findings in Table 2.

Table 2: Patterns of EU External Governance and Interdependence with Russia/CIS per sector

\begin{tabular}{|c|c|c|c|}
\hline EU-Ukraine External Governance & Ukraine- & Ukraine-Russia/CIS \\
$($ Rule/Policy Transfer $)$ & Russia/CIS & Interdependence \\
\hline
\end{tabular}




\begin{tabular}{|c|c|c|c|c|c|}
\hline & Substance & Extent & $\begin{array}{c}\text { Legal/Institutional } \\
\text { commitments }\end{array}$ & Legacy-driven & $\begin{array}{c}\text { Geo-political/ } \\
\text { economic }\end{array}$ \\
\hline $\begin{array}{l}\frac{\mathbb{E}}{E} \\
\text { E }\end{array}$ & $\begin{array}{l}\text { Title III PCA, } \\
\text { Sectoral } \\
\text { Agreements, AP } \\
\text { areas, WTO } \\
\text { acquis, } \\
\text { 'Deep trade' } \\
\text { regulatory } \\
\text { harmonization }\end{array}$ & $\begin{array}{l}\text { High level of } \\
\text { rule transfer: } \\
\text { - framework of } \\
\text { general } \\
\text { conditionality } \\
\text { helped by } \\
\text { economic } \\
\text { incentives, } \\
\text { procedural } \\
\text { mechanisms; } \\
\text {-WTO } \\
\text { disciplines. }\end{array}$ & $\begin{array}{l}\text { Participation in } \\
\text { CIS bodies and } \\
\text { international } \\
\text { agreements } \\
\text {-Agreements } \\
\text { substantively and } \\
\text { institutionally } \\
\text { weak; } \\
\text {-no hard legal } \\
\text { constraints } \\
\text { (unless SES); } \\
\text { - Conducive WTO } \\
\text { process }\end{array}$ & $\begin{array}{l}\text { Some } \\
\text { institutional } \\
\text { legacies (e.g. } \\
\text { standards) }\end{array}$ & $\begin{array}{l}\text { Diminishing } \\
\text { economic } \\
\text { interdependen } \\
\text { ce }\end{array}$ \\
\hline 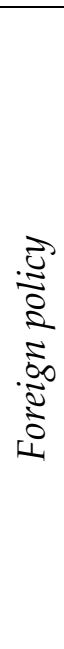 & $\begin{array}{l}\text { Alignment with } \\
\text { Common } \\
\text { Positions and } \\
\text { Joint } \\
\text { Operations, } \\
\text { Specific } \\
\text { Agreements }\end{array}$ & $\begin{array}{l}\text { High alignment } \\
\text { but some } \\
\text { important } \\
\text { exceptions. }\end{array}$ & $\begin{array}{l}\text { Selective and } \\
\text { cautious } \\
\text { participation in } \\
\text { international } \\
\text { agreements. }\end{array}$ & $\begin{array}{l}\text { High } \\
\text { inherited } \\
\text { legacies in } \\
\text { some fields } \\
\text { (e.g. Black } \\
\text { Sea Fleet) }\end{array}$ & $\begin{array}{l}\text { High geo- } \\
\text { political } \\
\text { interdependen } \\
\text { ce }\end{array}$ \\
\hline
\end{tabular}




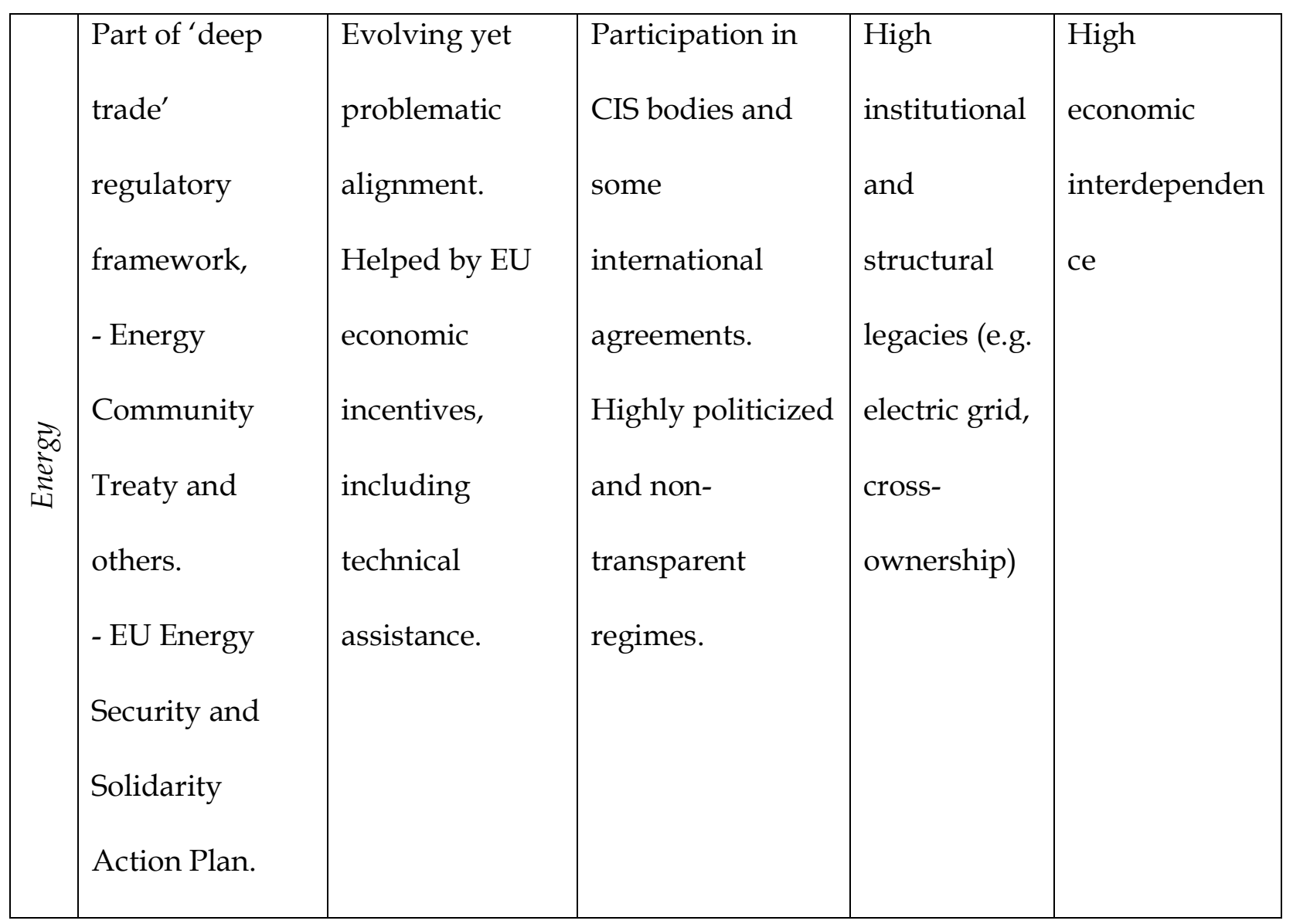

As it can be seen, in trade constraints to EU rule transfer are low at present. The institutional engagement of the Ukraine in the CIS trade regime is soft and flexible. The progressive move towards deep trade arrangements between EU and Ukraine has entailed a growing departure from the inherited interdependences in some areas, such as standards. The WTO as an international framework of norms to which Russia also aspires facilitates rule adoption by the Ukraine.

In foreign and security policy, interdependence remains important despite the formal alignment of Ukraine with most EU statements and positions. In this area we find a clash of the EU's soft approach and Russia's 
politics of power that illuminates another important constraint to external governance. Russia's strongly defined, 19 $9^{\text {th }}$ century concept of sovereignty not only clashes with EU norms in this area but leads to Russian actions which the EU is clearly powerless to counteract with external governance tools.

In energy, Ukraine's integration into EU's energy market as a part of a deep trade arrangement requires the adoption of a set of regulatory standards. In this area, CIS institutional arrangements are soft, but in spite of their weakness, the existing infrastructural interdependence and Russia's use of energy policy as a geopolitical tool (Lo, 2002), clearly limit the scope for EU rule transfer.

Thus, we identify differences in the extent of interdependence with Russia: it is low and receding in trade; yet in energy it is high in view of Russia's monopoly position and control over infrastructure. We also find differences in the interdependence patterns across policy areas. Russia has used mostly institutional levers in trade and mostly power policies in energy and foreign policy to constrain rule/policy adoption and implementation. Similarly, we see a differing depth of the effect on EU governance ranging from constraints of rule and policy selection (mostly in energy and FCSP) to primary effects on rule implementation (in trade).

These findings are in line with the power model defined by Lavenex and Schimmelfennig (2009), which expects incentives and costs for domestic governments to be decisive in adoption of external rules. The current 
restrictions to the EU's effective governance posed by Russia's power may be diminished if the EU were to offer the Ukraine a genuine prospect for membership, as enlargement might change the cost benefit calculation of domestic actors and increase the EU's hierarchical power.

The notion of governance presupposes forms of organization that go beyond hard notions of external and internal sovereignty (Lavenex 2004: 682). For contemporary Russia, however, the idea of sovereignty is at the center of its view of itself, its neighbours and the state system in Europe. The Russian worldview may not include understanding of external governance as a projection of the EU's own multi level governance system. In the apt words of Krastev (2008), the clash between EU and Russia is ultimately a clash between a post-modern state, embodied by the EU and the traditional modern state, embodied by Russia. In the Ukraine, more so than in any other part of the world, the successful spread of EU's external governance may end where a strong notion of traditional power reasserts itself.

\section{References}

Concept on the Foreign Policy of the Russian Federation of 12 July 2008, <www.kremlin.ru/text/docs/2008/07/204108.shtml> consulted on 4 September 2008.

Cremona, M. (2008) ‘The ENP as a Framework for Modernization', EUI Max Weber/Law Department Conference papers 23/24 May 2008. 
Cremona, M. and Hillion, C. (2006) 'L'Union fait la force? Potential and Limitations of the European Neighbourhood Policy as an Integrated EU Foreign and Security Policy', EUI Working Papers Law No. 2006/39.

De Souza, V. (2008) 'The Economic Aspects of the Energy Sector in the CIS Countries', CASE Economic papers 327/June 2008, http://ec.europa.eu/economy_finance/publications/publication12678_en.p df.

Dodsworth, J. et al. (2002) 'Cross-Border Issues in Energy Trade in CIS Countries', IMF Policy Discussion Paper 02/13 December 2002.

Dragneva, R. (2004) ‘Is “Soft” Beautiful? Another Perspective on Law, Institutions, and Integration in the CIS', Review of Central and East European Law 29: 279-324.

Dragneva, R. and Dimitrova, A. (2007) 'Patterns of Integration and Regime Compatibility: Ukraine Between the CIS and the EU', in K. Malfliet, L. Verpoest and Vinokurov, E. (eds.) 'The CIS, the EU and Russia: Challenges of Integration', Palgrave/Macmillan.

Dragneva, R. and De Kort, J. (2007) 'Legal Regime for Free Trade in the CIS', 56 International and Comparative Law Quarterly 2007: 233-266.

Dusseault, D. (2007) ‘Over a Barrel: Dependency Theory and the Energy Sector in the CIS', in Dusseault, D. (ed.), The CIS: Form or Substance?, Aleksanteri Institute. 
Emerson. M et al. (2006) 'The Prospect of Deep Free Trade Between the EU and Ukraine', CEPR, Brussels.

Euractiv: (2008) ‘Grasprom clause Issues Russia Ultimatum for Energy Cooperation, at http:/ / www.euractiv.com/en/energy/gazprom-clause-issuesrussia-ultimatum-energy-operation/article-166888, consulted 9 December 2008.

ENP Framework, at < http://europa.eu.int/eurlex/en/com/cnc/2003/com2003_0104en01.pdf>, at 17.

European Commission Staff Working Document, (2006a) accompanying the Commission Communication to the Council and the European Parliament on Strengthening the European Neighbourhood Policy, ENP Progress report Ukraine, \{Com (2006) 726 final\}, Brussels 4 September 2006 SEC (2006) $1505 / 2$

European Commission (2006b) Communication from the Commission to the Council and the European Parliament on Strengthening the ENP, COM(2006) 726 final, Brussels, 4 December 2006.

European Commission, (2008a) European Neighbourhood Policy: Ukraine, MEMO/08/215, Brussels, 3 April 2008.

European Commission, External relations with the Ukraine, at <http://europa.eu.int/comm/external_relations/ukraine/intro/index.htm \#pol> 
European Commission, (2008b) Staff Working Document Accompanying the Communication from the Commission to the Council to the European

Parliament, Implementation of the European Neighbourhood Policy in 2007'. Progress report Ukraine, SEC (2008) 402, 3 April 2008.

European Commission, (2008c) Press Release, 'Securing your energy future: Commission presents energy security, solidarity and efficiency proposals', IP/08/1696, 13 November 2008.

European Parliament Resolution on the results of Ukraine elections of 13 January 2005, No. P6_TA(2005)0009.

Ferrero-Waldner, B. (2006) ‘The European Neighbourhood Policy: The EU’s Newest Foreign Policy Instrument', European Foreign Affairs Review, 11:139142.

Freinkman L. et al. (2004) ‘Trade Performance and Regional Integration of the CIS Countries', WB Working Paper No. 38.

Friis, L. (1998) 'The End of the beginning of Eastern Enlargement Luxembourg Summit and Agenda-Setting' EIoP 2(7) at http:/ /eiop.or.at/eiop/texte/1998-007a.htm

Godzimirski, J. (2007) 'Russia and the CIS: Spaces, Paradigms and Patterns', in D. Dusseault, (ed.) The CIS: Form or Substance?, Aleksanteri Institute.

Gstöhl, S. (2008) ‘A Neighbourhood Economic Community - finalité économique for the ENP?', EU Diplomacy Papers 3/2008. Jonson, L. (2004) Vladimir Putin and Central Asia, Taurus. 
Hillion, C. (2007) 'Mapping Out the New Contractual Relations between the EU and Its Neighbours: Learning from the EU-Ukraine 'Enhanced Agreement', European Foreign Affairs Review 12, 160-182.

Kelley, J. (2006) ‘New Wine in Old Wineskins: Promoting Political reforms through the New European Neighbourhood Policy', Journal of Common Market Studies, 44(1): 29-55.

Kobrinskaya, I. (2007) 'The Post-Soviet Space: From the USSR to the CIS and Beyond', in Malfliet, K. et al. (Eds.) The CIS, the EU and Russia: Challenges of Integration, Palgrave.

Krastev, I, (2005) 'Russia's post Orange Empire' Open Democracy, at www.opendemocracy.net, 20 October 2005.

Krastev, I. (2008) 'The EU, Russia and the Crisis of the Post Cold War European Order', Europe's World, summer 2008, at:

http://www.europesworld.org/EWSettings/Article/tabid/191/ArticleTyp e/articleview/ArticleID/20551/Default.aspx

Lavenex, S. and Schimmelfennig, F. (2009) 'EU rules beyond EU borders: theorizing external governance in European politics' Journal of European Public Policy, forthcoming.

Lavenex, S. (2004) 'EU External Governance in “wider Europe"' Journal of European Public Policy, 11(4): 680-700.

Lo, B. (2002) Russian Foreign Policy in the Post-Soviet Era: Reality, Illusion, and Mythmaking, Palgrave. 
Melyantsou, D. and Kazakevich, A. (2008) ‘Belarus's Relations with Ukraine and Lithuania before and after 2006 Presidential Elections', Lithuanian Foreign Policy Review, 20, at: http://www.lfpr.lt/index.php?id=114

Razumkov centre, (2007a) 'Public Monitoring of the Ukraine - EU Action Plan, National Security and Defense 2007: Ukraine-EU: Towards a new phase of cooperation' 5: 89, at www.uceps.com.ua.

Razumkov centre, (2007b) 'Energy Security Briefing', at: www.uceps.com.ua.

Razumkov Centre, (2008) 'The EU Gas Market: State and Trends of

Development', National Security and Defence Magazine, 8, at www.uceps.com.ua.

Rettman, A. (2008) 'Germany and Russia threaten EU-Ukraine relations', EU Observer, 28 August 2008, at http://euobserver.com/24/26653, consulted 4 September 2008.

Shapovalova, N. (2008) 'The New Enhanced Agreement between the EU and Ukraine: Will it further Democratic Consolidation?', FRIDE Working paper No. 62/June 2008.

Silina, T. (2003) 'The SES Choice', Zerkalo Nedeli 20-26 September 2003, <www.mirror-weekly.com/ie/print/42213>.

Silina, T. (2008) 'Anatoliy Gritsenko: The Biggest Threat to the Ukraine is Us' Zerkalo Nedeli, \# 30 (709) 16 - 22 August 2008, at:

http://www.mw.ua/1000/1550/63775/, consulted 3 September 2008. 
Stern, J. (2005) The Future of Russian Gas and Gasprom, Oxford: Oxford University Press.

Sushko, O. et al. (2008)' The New Enhanced Agreement between Ukraine and EU: Proposals of Ukrainian Experts', KAS Policy Paper 8/2008.

Terekhin, L. (2005) Ukraina namerena razshiriat' stepen' integratsii v EEP', www.rian.ru.

Timoshenko, Y. (2005) ‘Ukraina Stala Liderom v formirovanii kontseptsii EEP', at www.rian.ru.

Vinokurov, E. (2007) 'Russian Approaches to Integration in the Post-Soviet Space in the 2000s', in Malfliet, K. et al. (Eds.) The CIS, the EU and Russia: Challenges of Integration, Palgrave.

Vinokurov, E. (2008) 'The CIS Common Electric Power Market', Eurasian Integration Yearbook, 81-101.

Willerton, J. and Beznosov, M. (2007) 'Russia's Pursuit of its Eurasian Security Interests: Weighing the CIS and Alternative Bilateral-Multilateral Arrangements', in Malfliet, K. et al. (eds) The CIS, the EU and Russia: Challenges of Integration, Palgrave.

Wolczuk, K. (2007) ‘Adjectival Europeanisation? The Impact of EU Conditionality on Ukraine under the European Neighbourhood Policy', ERI European Research Working Paper Series No. 18.

Wolczuk, R. (2007) 'Ukraine - A Partial but Reluctant CIS Member', in Dusseault, D. ed., The CIS: Form or Substance?, Aleksanteri Institute. 
World Bank Ukraine Trade Policy Study (2004) WB Report No. 29684-UA.

Yushchenko, V. (2005), 'Yushchenko: Sozdanie nadnatsional'nykh organov v ramkakh EEP prezhdevremenno', at

<www.newsukraina.ru/news.html?nws_id+402535>.

Authors note:

Antoaneta Dimitrova is Lecturer at the Department of Public Administration of Leiden University, The Netherlands

Rilka Dragneva is Lecturer at the School of Law

University of Manchester, UK

Address for correspondence:

Antoaneta Dimitrova,

Dimitrova@fsw.leidenuniv.nl

Department of Public Administration,

Wassenaarseweg 52, P. O. Box 9555, 2300 RB Leiden, The Netherlands

Word count including endnotes: 8,969 words

\footnotetext{
${ }^{1}$ For reasons of consistency, references to interdependence here follow Lavenex and Schimmelfennig in this volume and do not aim to reflect the wider international relations literature on this topic.

${ }^{2}$ This section draws on Dragneva and Dimitrova (2007).

${ }^{3}$ More details in Dragneva and Dimitrova (2007).

${ }^{4}$ The PCA also incorporates a Declaration concerning Article 102, which clarifies 'special urgency' as meaning cases of 'material breach' under the 1969 Vienna Convention. (C. Hillion, 2005). Such a suspension would be a very complex process on behalf of the EU.

5 'The stake in the internal market' reward has developed further with the EC Commission Communication on Strengthening the ENP, $\operatorname{COM}(2006) 726$ final, referring to an 'economic
} 
community'. This document contains stronger references to 'the application of shared regulatory frameworks' (Gstohl, 2008).

${ }^{6}$ See also the decree by Yushchenko of 16 June 2005 on 'Urgent Measures for Activation of Ukraine's Participation in the Formation of SES'.

${ }^{7}$ E.g. on textiles (Article 21 PCA, Sectoral agreement of March 2005), steel (Article 22 PCA, Sectoral agreement of December 2004), and nuclear materials (Article 23 PCA, Sectoral agreement of July 1999).

${ }^{8}$ There are exemptions concerning some 'sensitive' goods, primarily agricultural commodities, traded subject to tariffs and quotas on a MFN basis, most specifically, with Belarus, Georgia, Kazakhstan, Moldova, Russia, and Uzbekistan.

${ }^{9}$ The only duty imposed on the country which enters another preferential or integration agreement is to notify its partners of the terms of its participation.

${ }^{10}$ A World Bank study suggests that such a step could lead to adverse effects for Ukraine if Russia uses its superior bargaining power in imposing its tariff structure as the SES common external tariff (World Bank, 2004).

${ }^{11}$ See also Barbé et al. in this volume for an in-depth analysis.

12 An important aspect of this 'energy addiction' is the extreme domestic inefficiency of consumption, which the EU is also seeking to address (Emerson et al., 2006).

${ }^{13}$ As Emerson et al. show, out of 5 refineries, 4 are held by Russian capital. Most of Russian foreign direct investment in Ukraine is concentrated in the fuel and energy sector (2006: 37). 